\title{
СТРУКТУРА ІНСТИТУТУ КОНСТИТУЦІЙНО-ПРАВОВОЇ ВІДПОВІДАЛЬНОСТІ ДЕРЖАВИ
}

Бакумов О. С.

\begin{abstract}
у статmі подається аналіз структури інституту конституційно-правової відповідальності держави. Наголошується, що процес оформлення інституту конституційно-правової відповідальності держави в Україні не $\epsilon$ на сьогодні завершеним. Свідченням тому $є$ слабкість таких елементів зазначеного інституту, як процедур но-процесуального складника, брак визначеності у співвідношенні адміністративних і судових (процесуальних) елементів у процесі реалізації конституційно-правовоі відповідальності держави, незавершеність юридизаціі системи конституційно-правових санкцій у сфері відповідальності держави.
\end{abstract}

Визначено, що основними видами юридичної відповідальності держави слід визнати: за сферою прояву: позитивну та негативну відповідальність; за суб'єктом прояву: відповідальність перед особою, суспільством, нинішніми та прийдешніми поколіннями; залежно від наявності судової чи позасудової інстанції настання і визначення: судову та позасудову відповідальність; залежно від повноти процесуально-правової забезпеченості: процесуально забезпечену та процесуально недостатньо забезпечену; залежно від нормативно-правового рівня фіксації: передбачені конституційними та/або законодавчими нормами; залежно від наявності чи відсутності власної вини: відповідальність власне держави та відповідальність держави за діі державних органів чи їх посадових осіб.

3'ясовано, що конституційно-правовими санкціями як елементом інституту конституційно-правової відповідальності держави є лише конституційно-правові за галузевою ознакою санкції.

Ключові слова: юридична відповідальність держави, конституційно-правові відносини, принципи самозобов'язування держави, конституційно-правові режими функціонування держави.

В статье дается анализ структуры института конституционно-правовой ответственности. Отмечается, что процесс оформления института конституционно-правовой ответственности в Украине не является на сегодня завершенным. Свидетельством тому является слабость таких элементов указанного института, как процедурно-процессуальной составляющей, отсутствие определенности в соотношении административных и судебных (процессуальных) элементов в процессе реализации конституционно-правовой ответственности, незавершенность юридизации системы конституционно-правовых санкций в сфере ответственности.

Определено, что основными видами юридической ответственности следует признать: по сфере проявления: положительную и отрицательную ответственность; по субъекту проявления: ответственность перед лицом, обществом, нынешними и грядущими поколениями; в зависимости от наличия судебной или внесудебной инстанции наступления и определения: судебную и внесудебную ответственность; в зависимости от полноты процессуально-правовой обеспеченности: процессуально обеспеченную и процессуально недостаточно обеспеченную; в зависимости от нормативно-правового уровня фиксации: предусмотренные конституционными и/или законодательными нормами; в зависимости от наличия или отсутствия собственной вины: ответственность собственно государства и ответственность государства за действия государственных органов или их должностных лиц.

Выяснено, что конституционно-правовыми санкциями как элементом института конституционно-правовой ответственности являются лишь конституционно-правовые по отраслевому признаку санкции.

Ключевые слова: юридическая ответственность государства, конституционно-правовые отношения, принципь самообязанности государства, конституционно-правовые режимы функционирования государства.

The article analyzes the structure of the institute of constitutional and legal responsibility of the state. It is emphasized that the process of registration of the Institute of Constitutional Legal Liability of the State in Ukraine is not yet complete. This is evidenced by the weakness of such elements of the said institute as: procedural and procedural component, lack of certainty in the ratio of administrative and judicial (procedural) elements in the process of realization of the constitutional and legal responsibility of the state, incompleteness of the legalization of the system of constitutional and legal sanctions in the sphere of state responsibility.

It is determined that the main types of legal responsibility of the state should be recognized: by area of manifestation: positive and negative responsibility; the subject of the manifestation: responsibility to the individual, society, present and future generations; depending on the existence of a judicial or extrajudicial instance, the onset and determination of: judicial and extrajudicial liability; depending on the completeness of procedural legal support: procedurally secured and procedurally insufficient; Depending on the legal level of fixation: provided by the constitutional and/or legislative norms; depending on the presence or absence of their own guilt: responsibility of the state itself and responsibility of the state for actions of state bodies or their officials. It has been found out that constitutional-legal sanctions, as an element of the institution of constitutional-legal responsibility of the state, are only constitutional-legal according to the sectoral feature of the sanction. All other sanctions that have a different sectoral nature and go beyond the substantive limits of constitutional law cannot be regarded as a structural element of the institution of constitutional and legal responsibility of the state.

Attention is drawn to the fact that a thorough scientific understanding of the structural features of the constitutional and legal responsibility of the state should serve the practical purposes of ordering and systematization in the constitutional and legal regulation of the said institute in the system of constitutional law institutions in order to optimize the institutional capacity of the state's legal capacity.

Key words: legal responsibility of the state, constitutional-legal relations, principles of self-binding state, constitutional-legal regimes of functioning of the state. 
Постановка проблеми та іï актуальність. Зовнішньою формою функціонування конституційно-правової відповідальності держави $\epsilon$ іï існування як окремого інституту конституційного права. В цій іпостасі вона виявляється сукупністю конституційно-правових норм, що визначають іï підстави, порядок реалізації та конституційно-правові санкції. Означений інститут також $\epsilon$ складним комплексом конституційно-правових норм, що прямо чи опосередковано регулюють питання юридичної відповідальності держави у площині конституційно-правових відносин. Тому осердям означеного інституту $є$ норми, розміщені в Конституції держави, хоча лише цими нормами згаданий інститут не вичерпується, адже конституційне право має в своєму «арсеналі» чимало й інших джерел, зокрема законів, що так чи інакше конкретизують, розвивають, продовжують конституційні норми щодо юридичної відповідальності держави.

У питанні визначення структури цього інституту досі бракує чіткості й визначеності, що здебільшого зумовлене загальною неусталеністю генерального інституту конституційно-правової відповідальності в конституційному праві України як галузі права. Натепер можна стверджувати як про концептуальну (доктринальну), так і про нормативно-правову незавершеність оформлення інституту конституційно-правової відповідальності держави в системі інститутів конституційного права України.

Вирішуючи питання структурування цього інституту на складники (компоненти), слід, вочевидь, виходити із загального розуміння структури інституту конституційного права, що доктринально опрацьовується в межах теорії юридичної відповідальності та в теорії конституційного права, а також поєднувати такий концептуальний підхід із розкриттям специфіки елементів саме інституту конституційно-правової відповідальності держави, враховуючи специфічність суб'єкта такої відповідальності, підстав і порядку їі застосування, санкцій тощо.

Аналіз останніх досліджень і публікацій. У сучасній конституційно-правовій науці питання структурування інститутів конституційного права стали предметом досліджень Л.В. Андріченко, В.О. Виноградова, Н.М. Колосової, О.В. Олькіної, В.Л. Федоренка, О.В. Чепуса, С.М. Шабуневич та інших.

В юридичній літературі визначаються такі загальні ознаки правового інституту: наявність єдності правових норм; відносна відособленість у певних частинах (розділах) нормативного правового акту; спрямованість на врегулювання певного виду суспільних відносин. Цей інститут $\epsilon$ структурною одиницею системи права, яка слідує за підгалузями права. При цьому інститут юридичної відповідальності $є$ основою всієї системи права, 3 його допомогою забезпечується дія різних правових приписів, регулюються й охороняються суспільні відносини. На макрорівні сукупність галузевих інститутів юридичної відповідальності утворює міжгалузеве утворення - міжгалузевий інститут права [1].

Мета статті полягає у розкритті особливостей структури інституту конституційно-правової відповідальності держави в межах науки конституційного права.

Виклад основного матеріалу. На сьогодні в науці конституційного права зустрічається декілька підходів до виокремлення й аналізу структури інституту в межах цієї галузі права. Вони багато в чому виявляються похідними від наукових уявлень про інститути конституційного права загалом. Здебільшого на науко- во-методологічному рівні виокремлюють три аспекти структури будь-якого об'єкта: кількість складників; порядок їх розташування; характер залежності між ними [2]. 3 цього ж погляду складний правовий інститут складається з кількох взаємопов'язаних субінститутів, а ті - з окремих правових норм. У цьому сенсі конституційно-правовий інститут відповідальності держави слід розглядати як елемент комплексного правового інституту відповідальності держави, а той у свою чергу - як складник міжгалузевого інституту юридичної відповідальності. При цьому критеріями структурування такого інституту $є$ галузевий і суб'єктний. За галузевим критерієм автор виокремлює у системі конституційного права інститут конституційно-правової відповідальності, а за суб'єктним критерієм цей же інститут розкладає на кілька складників, де однією з них $є$ інститут конституційно-правової відповідальності держави, хоча і цей інститут може бути розкладний на певну систему складників [3, с. 57].

Варто відразу зробити застереження щодо співвідношення понять «конституційно-правова відповідальність держави» та «інститут конституційно-правової відповідальності держави». Ці два поняття $\epsilon$ близькими, проте не тотожними за змістом. Якщо поняття відповідальності вказує на певну об'єктивну специфіку суспільних відносин у сфері цього виду юридичної відповідальності, то поняття інституту конституційно-правової відповідальності - на особливість внутрішньої побудови, організації та взаємодії норм і їх сукупностей у межах певного конгломерату конституційно-правових норм, а саме тих із них, які опосередковують відносини у сфері конституційно-правової відповідальності держави як суб'єкта права.

Із точки зору А.О. Кондрашова, структуру конституційно-правової відповідальності складають підстави, заходи, суб'єкти, інстанції і процедури реалізації цієї відповідальності [4]. Іноді в конституційно-правовій науці називають дещо ширше коло структурних елементів конституційно-правової відповідальності: сукупність конституційно-правових норм, що закріплюють конституційно-правові делікти; конституційно-правові санкції і принципи їх застосування; коло суб'єктів, уповноважених їх застосовувати; процедура застосування таких санкцій [5]. Також іноді у структурі конституційно-правової відповідальності виокремлюють норми, що регулюють підстави настання цієї відповідальності; норми, що встановлюють склади конституційно-правових деліктів; норми, що встановлюють заходи державного примусу; норми, що встановлюють порядок притягнення до конституційно-правової відповідальності, призначення покарання, виконання покарань тощо [6, с. 129-130].

У колективній монографії «ннститути конституційного права» iї автори стверджують, що інститути в рамках конституційного права $€$ системою взаємопов'язаних елементів, що не заважає їх будові в рамках певної ієрархічної послідовності [7, с. 9]. У структурному плані інститут конституційного права, на думку О.Є. Постнікова, $\epsilon$ сукупністю закріплених у законодавстві правових норм, які регулюють однорідні суспільні відносини у сферах організації публічної влади, основ правового статусу особистості та устрою держави [8].

3 точки зору В.Л. Федоренка, інститут конституційного права України, як і будь-яка інша конституційна система (підсистема), має свою внутрішню побудову. 
При цьому, на думку вченого, йдеться «не про довільну, а про систематизовану сукупність норм права, об'єднаних у складі інституту права. У цьому сенсі інститут права $\epsilon$ підсистемою права, передбачає наявність їі внутрішньої структури, обов'язковими елементами якої $\epsilon:$ а) структурні елементи інституту права; б) система юридичних зв'язків між ними і їх характер».

Відповідно до широти охоплення предметної проблематики можна виокремити вузьке та широке тлумачення структури цього інституту. У рамках вузького тлумачення інститут конституційно-правової відповідальності держави структурно зображується як сукупність і внутрішньо закономірна упорядкованість розташування конституційно-правових норм, які опосередковують відносини у сфері конституційно-правової відповідальності держави. В цій інтерпретації основним елементом структури означеного інституту виступають відповідні галузеві норми, які регулюють відносини конституційно-правової відповідальності держави як суб'єкта правовідносин.

У рамках широкого правотлумачення структуру інституту конституційно-правової відповідальності держави складають відповідні норми конституційного права, а також відносини між ними і їх характер. Крім того, в рамках широкого правотлумачення інститут конституційно-правової відповідальності держави може розглядатися в статичному та в динамічному вимірах. Так, у статичному розрізі він $\epsilon$ сукупністю певних норм і підінститутів конституційного права, а в рамках динамічного виміру - процесом невпинного розвитку, оновлення, функціонування конституційно-правових норм, які опосередковують конституційно-правову відповідальність держави, внаслідок яких цей інститут набуває ознак рухомості [9].

На думку В.Л. Федоренка, основними компонентами структури інституту конституційного права України $\epsilon$ нормативний зміст інституту конституційного права України як цілісної юридичної категорії; принципи існування та дієвості інституту конституційного права України; функції інституту конституційного права України; конституційно-правовий статус учасників правовідносин, які регулюються нормами інституту конституційного права України (права й обов' язки основних інституціоналізованих суб'єктів, організаційно-правові форми ïx діяльності тощо); конституційно-правовий режим інституту конституційного права України; гарантії реалізації інституту конституційного права України [10, с. 44].

Сутність структури інститутів конституційного права України визначається змістом запропонованих складників (компонентів) цієї структури. На думку автора, елементом конституційно-правової відповідальності держави не $\epsilon$ і не може бути іï конституційно-правовий статус, адже така відповідальність навпаки $\epsilon$ елементом означеного статусу. Натомість конституційно-правовий статус держави зазвичай охоплює сукупність прав, обов'язків і відповідальності держави у сфері конституційно-правових відносин. Тому розгляд конституційно-правового статусу як елемента конституційно-правової відповідальності держави автор вважає хибним підходом.

Першоосновою будь-якого інституту конституційного права України і визначальним складником його структури $\epsilon$ нормативний зміст цього інституту. Він складається з норм Конституції України та інших актів конституційного права, які опосередковують конституційно-правові відносини щодо юридичної відповідальності України. При цьому в юридичній науці встановлено безпосередній та опосередкований способи встановлення такої відповідальності держави. Безпосередній спосіб об'єктивований у конституційних нормах про відшкодування завданої державою та її органами шкоди. Опосередкований спосіб передбачає встановлення певних універсальних принципів, які відображають внутрішні властивості держави як правового устрою та принципи взаємовідносин держави і особистості, та спеціальних, серед яких виокремлюють принципи самозобов'язування держави, які закріплюють законодавчі обмеження активності держави стосовно особи шляхом запровадження обов' язків держави щодо забезпечення і захисту прав особи; принципи-гарантії, які встановлюють відповідальність державних органів і посадових осіб із дій, що порушують права людини; принципи-правомочності, які закріплюють права людини щодо захисту її прав і свобод [11, с. 14].

Важливе місце серед конституційно-правових норм, які складають структуру інституту конституційно-правової відповідальності держави, становлять норми, що опосередковують підстави ії настання. Так, усталеною для конституційного права традицією $\epsilon$ виокремлення серед таких норм правил, які опосередковують нормативні (конституційно-правові) та фактичні підстави цієї відповідальності. Конституційно-правовою підставою відповідальності завжди буде наявність відповідної конституційно-правової норми (декількох норм), які передбачають можливість, умови притягнення та санкції (міри) конституційно-правової відповідальності. Нормативною основою конституційно-правової відповідальності $\epsilon$ конституційне та законодавче закріплення фактичних неправомірних дій, у разі скоєння яких і настає конституційно-правова відповідальність. Фактичною підставою виникнення конституційно-правової відповідальності $€$ конституційний делікт, скоєний суб'єктом конституційно-правових відносин [12, с. 10].

Деякі автори, як В.О. Виноградов, пропонують розглядати три підстави конституційно-правової відповідальності: 1) нормативну; 2) фактичну; 3) процесуальну [13, с. 42-47]. У цьому сенсі нормативною підставою конституційно-правової відповідальності держави виступатиме сукупність конституційно-правових норм, що встановлюють відповідальність держави за дії чи бездіяльність, які порушують права і свободи фізичних та/або юридичних осіб, а також ті, що закріплюють обов'язки держави щодо їх захисту і забезпечення. Фактичною підставою конституційно-правової відповідальності держави тут будуть конкретні дії та/чи бездіяльність державних органів та/чи їх посадових осіб, які призвели до порушення прав і свобод людини і громадянина, конституційного правопорядку, інших конституційних цінностей. Процесуальною підставою для конституційно-правової відповідальності держави $\epsilon$ встановлення уповноваженим суб'єктом у спеціальному правозастосовному акті (судовому чи позасудовому) форм і заходів конституційно-правової відповідальності держави за конкретне правопорушення у сфері конституційно-правових відносин.

Натепер «інститут позасудового, а тим паче добровільного відшкодування шкоди, завданої діями органів влади, в Україні відсутній. Відсутній навіть чіткий і про- 
зорий концептуальний підхід до його функціонування. Також проблема полягає в тому, що в деяких випадках особа не може реалізувати своє право, оскільки відсутній механізм його реалізації. Часто не відшкодовується шкода особам, права і інтереси яких були порушені внаслідок неналежного виконання своїх обов'язків службовими та посадовими особами органів виконавчої влади та місцевого самоврядування. Органи влади приймають рішення про скасування незаконних рішень посадових і службових осіб без призначення виплати відповідної компенсації постраждалим. Тобто, зараз процедура прийняття, скасування та застосування примусу до прийняття індивідуальних актів не завжди передбачає відшкодування шкоди, завданої дією незаконного індивідуального акту. Окрім того, нинішній стан справ у сфері відшкодування шкоди передбачає можливість невиплати коштів після прийняття рішення про її відшкодування» [14, с. 16]. Тож варто погодитися з висновком С. Яремчук у тому, що з метою усунення відповідної прогалини варто було б розробити спеціальний закон [15], в якому необхідно передбачити процедуру притягнення держави до відповідальності зокрема і за ухилення від виконання судових рішень про стягнення з неї коштів на користь третіх осіб.

Іншим важливим складником структури інституту конституційно-правової відповідальності держави $\epsilon$ принципи функціонування зазначеного правового інституту. Тут слід виокремити дві великі групи принципів. 3 одного боку, це принципи, що опосередковують керівні, визначальні ідеї щодо функціонування держави, iï органів і посадових осіб, а також основні принципи юридичної відповідальності як комплексного інституту правової системи держави. 3 іншого боку, це спеціально-юридичні принципи, що опосередковують саме спеціальні керівні настанови щодо застосування конституційно-правової відповідальності держави. 3-поміж основних принципів конституційно-правової відповідальності держави автор виокремлює принципи конституційності, законності, пріоритету прав людини, верховенства права, невідворотності юридичної відповідальності тощо.

Щодо спеціальних принципів конституційно-правової відповідальності держави, то тут слід назвати принципи народного суверенітету, гуманізму, підзвітності і підконтрольності державної влади, відшкодування державою завданої ії органами і посадовими особами шкоди тощо. Якщо погодитися з висновком В.Л. Федоренка в тому, що «принципи інститутів конституційного права України $\epsilon$ поліфункціональними і визначають керівні ідеї, покладені в основу того чи іншого інституту конституційного права України; загальні засади функціонування таких інститутів; правові основи діяльності й поведінки учасників конституційно-правових відносин, урегульованих нормами того чи іншого інституту конституційного права тощо» [2], то варто визнати і їхню особливість у розрізі функціонування інституту конституційно-правової відповідальності держави. Ці принципи прямо чи евентуально позначені в нормах Конституції України та/або виводяться зі змісту ії положень, знаходять прояв і конкретизацію в поточному законодавстві, правових позиціях Конституційного Суду України, змістовно насичують законодавчий механізм гарантування реальності та ефективності згаданого інституту.

Ще одним складником конституційно-правового інституту відповідальності держави $\epsilon$ його функції.
Це групи норм конституційного права України, які визначають основні напрями і види впливу цього інституту конституційного права на суспільні відносини, які $\epsilon$ предметом їх правового регулювання. Як зауважує В.Л. Федоренко, «важливість цього структурного компоненту інституту $є$ очевидною, тому що кожен окремо взятий інститут конституційного права $\epsilon$ нормативним виміром окремого виду чи підвиду функцій цієї галузі права». Адже конституційно-правова відповідальність $\epsilon$ функціональним інститутом конституційного права [16, с. 79].

У науці конституційного права зазвичай виокремлюють чотири провідних функції конституційно-правової відповідальності: 1) охоронна - упорядковує конституційні правовідносини та формує правомірну поведінку їх учасників, що сприяє підтриманню режиму конституційної законності, стабільності політичної системи, дотриманню прав та свобод людини і громадянина; 2) превентивна (виховна) - направлена на недопущення порушення конституційно-правових норм і розвитку протиправних відносин. Зокрема, конституційні обов'язки та заборони, погроза застосуванням конституційних санкцій виключають можливість вчинення деліктів; 3) каральна (репресивна) - реалізується у випадку скоєння конституційних деліктів та полягає у застосуванні заходів примусового державного впливу (при цьому часто виконання каральної функції спричиняє реалізацію каральних функцій інших видів юридичної відповідальності, що пов'язано із наділенням деяких суб'єктів конституційних правовідносин імунітетами); 4) компенсаційна (відновна) - пов'язана з усуненням правопорушень і вжиттям заходів із забезпечення належного функціонування державного апарату, реалізації конституційних прав і свобод людини та громадянина [16, с. 79].

Якщо реінтерпретувати зміст означених функцій конституційно-правової відповідальності держави, то вони, на думку автора, будуть такими: 1) охоронна упорядковує конституційні правовідносини та формує правомірну поведінку держави як суб'єкта права, сприяє підтриманню режиму конституційної законності, стабільності політичної системи, дотримання прав та свобод людини і громадянина в діяльності держави, іï органів і посадових осіб; 2) превентивна (виховна) - скерована на недопущення порушення конституційно-правових норм і виникнення протиправних відносин за участю держави; 3) каральна (репресивна) реалізується у випадку скоєння конституційних деліктів і полягає у застосуванні заходів примусового державного впливу на державу як на суб'єкта права, призводить до стягнень та інших соціально несприятливих для держави наслідків, обмежень у вільному розпорядженні державою наявними у неї ресурсами, коштами, а також до інших обмежень конституційно-правового характеру, що має негативні наслідки для держави як суб'єкта конституційно-правових відносин; 4) компенсаційна (відновна) - пов'язана з усуненням державою наслідків, вчинених нею, іï органами та/або посадовими особами цих органів правопорушень і вжиттям заходів із забезпечення належного функціонування державного апарату, реалізації конституційних прав і свобод людини та громадянина, усунення перешкод для їх реалізації, забезпечення захисту з боку держави.

За концептуальним підходом В.Л. Федоренка до структурних компонентів інституту конституційно-пра- 
вової відповідальності держави слід віднести відповідні конституційно-правові режими функціонування держави [2], що здається автору слушним з огляду на нетотожність умов та порядку здійснення державної влади за ординарного та особливого конституційних режимів. Якщо у підході згаданого автора «під конституційно-правовим режимом як складником структури інститутів відповідної галузі права слід розуміти настання передбачуваного і бажаного стану неухильного дотримання та виконання учасниками конституційно-правових відносин нормативних положень того чи іншого інституту конституційного права, особливо в частині їх прав і обов'язків за умови об'єктивації цих положень у чинному конституційному законодавстві України» [2], то в авторській інтерпретації під особливими конституційно-правовими режимами пропонується розуміти особливі порядки забезпечення прав і свобод громадян України, які проживають на територіях, у межах яких запроваджуються відповідні режими, що мають обмежений у часі, просторі та за колом осіб характер, передбачають істотні правообмеження щодо здійснення прав і свобод людини та громадянина, а також тягнуть суттєві зміни в організації та функціонуванні системи державної влади, відмінні від звичайних (ординарних) умов, встановлених Конституцією та законами України.

До числа особливих правових режимів віднесені надзвичайні (надзвичайного стану, воєнного стану, надзвичайної екологічної ситуації) та гібридні режими (режими АТО, ТОТ, ООС, зони відчуження довкола ЧАЕС). Основна відмінність між ними полягає в конституціалізації перших, які передбачають відступ держави від забезпечення низки конституційних прав і свобод людини та громадянина, та другими, які передбачають якісно менше обмеження людей у правах та викликані екстраординарними обставинами, безпосередньо не передбаченими Основним Законом України. Юридична відповідальність держави в умовах нормального та особливого (зокрема за надзвичайного або гібридного) конституційно-правового режиму не може бути тотожною, оскільки за умов особливого правового режиму відбувається обмеження у правах певного кола фізичних та юридичних осіб, модифікується як система державної влади, умови їх функціонування, так і характер взаємовідносин із фізичними та юридичними особами внаслідок збільшення кількості правообмежень і заборон у життєдіяльності останніх.

Зокрема, в умовах особливого конституційно-правового режиму держава бере на себе додаткові позитивні конституційно-правові зобов'язання, має виконувати, поряд зі звичайними, ще й додаткові правові зобов'язання, відповідаючи за їх належне виконання перед особою та суспільством загалом. Йдеться про виникнення у держави в умовах дії особливих правових режимів підвищеної конституційно-правової відповідальності, зумовленої накладенням додаткових правообмежень і заборон у сфері прав і свобод людини та громадянина, виникненням у держави нових (додаткових, хоч і строкових) конституційно-правових зобов'язань, належне виконання чи невиконання яких має зумовлювати додаткову конституційно-правову відповідальність поряд із відповідальністю, яку несе держава за ординарних умов свого конституційного функціонування.

Що стосується такого компоненту як гарантії конституційно-правової відповідальності держави, то тут автор вказує на те, що гарантування за сучасних умов $\epsilon$ невід'ємною умовою дієвості, реалістичності та ефективності будь-якого інституту конституційного права. Якщо ж мова заходить про такий відносно новий інститут конституційно-правової відповідальності, яким є інститут конституційно-правової відповідальності держави, то його гарантування полягає у свідомому створенні державою як суб'єктом права та безпосередньо народом як єдиним джерелом влади і носієм суверенітету сукупності таких нормативно-правових, організаційних та ідеологічних умов, за яких конституційно-правова відповідальність держави реалізується безперешкодно, невідворотно, на засадах гуманізму, пріоритету прав людини, верховенства права тощо.

На думку автора, гарантії конституційно-правової відповідальності держави тісно пов'язані із гарантіями реалізації конституційних прав і свобод людини та громадянина. Як зазначають П.М. Рабінович і М.І. Хавронюк, «гарантії реалізації конституційних прав і свобод людини та громадянина - це умови та засоби, принципи та норми, які забезпечують здійснення, охорону i захист зазначених прав, $\epsilon$ запорукою виконання державою та іншими суб'єктами правовідносини тих обов'язків, які покладаються на них із метою реалізації конституційних прав і свобод людини та громадянина» $[17$, с. 246]. 3 цього погляду гарантії конституційно-правової відповідальності держави - це сукупність умов і засобів, принципів і норм, які забезпечують реалізацію цієї відповідальності як невід'ємного складника гарантування прав і свобод людини та громадянина. Гарантії цієї відповідальності можна розглядати як матеріальні і процесуальні, організаційні та нормативні, економічні, соціальні, політичні та ідеологічні (духовні) тощо [18, с. 305-313]. На сьогодні можна спостерігати загальну неусталеність, слабкість гарантій конституційно-правової відповідальності держави, їхню нерозвинутість як у системі державного управління, так і в системі прямих і зворотних зв'язків влади із громадянами.

Нерозвинутими автору здаються і власне спеціально-юридичні гарантії реалізації конституційно-правової відповідальності держави, до яких, згідно із концептуальним підходом М.В. Вітрука, слід віднести конкретизацію меж прав та обов'язків держави як суб'єкта права; встановлення юридичних фактів, з якими пов'язується реалізація такої відповідальності; визначеність процедурно-процесуальних форм реалізації такої відповідальності тощо [18, с. 314]. Якщо «у більшості законів України гарантії тих чи інших інститутів конституційного права України, втілені в цих законах, об'єктивовані в самостійних статтях і розділах» [2], то у випадку конституційно-правової відповідальності держави в Україні про це говорити зарано.

Структурування інституту конституційно-правової відповідальності держави може бути здійснено не лише за специфікою розташування та характером зв'язку відповідних конституційно-правових норм, але і за предметними сферами прояву такої відповідальності та спрямованістю відповідного регулювання. Так, залежно від особливостей механізму (процедури, процесу) реалізації конституційно-правову відповідальність можна умовно розділити на такі види: відповідальність, що реалізується у судовому порядку; конституційно-правова відповідальність у формі прийняття рішення компетентним органом, який не $є$ органом судової влади; конститу- 
ційно-правова відповідальність у вигляді застосування форм безпосереднього народовладдя (наприклад, вибори чи референдум) [19, с. 552].

Конституційно-правова відповідальність держави як інститут конституційного права може також структуруватися у вигляді позитивної та негативної відповідальності. При цьому негативна відповідальність держави може бути розглянута в єдності двох структурних складників: відновлювально-компенсаційного та репресивно-карального. Залежно від предметної сфери негативна відповідальність держави може бути відповідальністю за порушення основ конституційного ладу; конституційних прав і свобод людини та громадянина; у сфері адміністративно-територіального устрою; у сфері здійснення управління державними справами тощо.

Відповідно до критичного аналізу наведених класифікаційних підходів до осмислення цього правового феномену основними видами юридичної відповідальності держави слід визнати: за сферою прояву: позитивну та негативну відповідальність; за суб'єктом прояву (перед ким конкретно держава несе відповідальність): відповідальність перед особою, суспільством, нинішніми та прийдешніми поколіннями; залежно від наявності судової чи позасудової інстанції настання і визначення: судову та позасудову відповідальність; залежно від повноти процесуально-правової забезпеченості: процесуально забезпечену та процесуально недостатньо забезпечену (чи незабезпечену); залежно від нормативно-правового рівня фіксації: передбачені конституційними та/або законодавчими нормами; залежно від наявності чи відсутності власної вини: відповідальність власне держави (як цілісного апарату) та відповідальність держави за дії державних органів чи їх посадових осіб (субсидіарну).

Автор звертає увагу і на місце санкцій у структурі інституту конституційно-правової відповідальності держави. Тут слід зробити три важливих застереження. По-перше, без наявності санкцій ані конституційно-правова відповідальність, ані відповідний правовий інститут, який їі регулює, не $\epsilon$ повними, завершеними, цілісними й реалістичними, дієвими. Тобто, санкції у структурі конституційно-правової відповідальності держави $\epsilon$ таким самим обов'язковим елементом, як і відповідальності будь-якого іншого суб'єкта конституційно-правової відповідальності.

По-друге, санкції конституційно-правової відповідальності зовсім не обов'язково повинні міститися в конституційно-правовій нормі, а можуть розміщуватися в інших галузевих санкціях, що пов'язано з особливостями галузі конституційного права [20, с. 10]. 3 цієї точки зору конституційно-правовими санкціями як елементом інституту конституційно-правової відповідальності держави $є$ лише конституційно-правові за галузевою ознакою санкції. Всі інші санкції, які мають іншу галузеву природу і виходять за предметні межі конституційного права, не можна розглядати в якості структурного елемента інституту конституційно-правової відповідальності держави.

По-третє, санкції конституційно-правової відповідальності держави не вичерпуються санкціями ретроспективного характеру, як вважає Н.М. Колосова $[21$, с. 110$] .3$ огляду на двоєдину - позитивну і негативну природу такої відповідальності - вони можуть мати як перспективний, так і ретроспективний характер. Тому $\epsilon$ підстави розглядати санкції у структурі інституту конституційно-правової відповідальності держави як складника структури цього правового інституту, який складається з конституційно-правових норм, що $є$ заходами державного (позитивного та негативного) впливу, застосовуються спеціально уповноваженими суб'єктами до держави внаслідок вчинення нею (відповідальність у разі вини самої держави), їі органами та/або посадовими особами (відповідальність без вини самої держави) конституційно-правового делікту, і виражаються у певних юридичних наслідках, які настають для держави як цілісного суб'єкта права.

Питання кола санкцій конституційно-правової відповідальності держави $є$ чи не найменш розробленим у конституційно-правовій літературі. Адже ті санкції, які у працях багатьох авторів досі вважалися класичними санкціями конституційно-правового характеру (відкликання депутатів, розпуск представницького органу влади тощо), для держави не можуть бути застосованими. Отже, йдеться про вироблення концептуального правового підходу, який дав би змогу виокремити саме властиві державі як суб'єктові конституційно-правових відносин санкції.

Висновки. Процес оформлення інституту конституційно-правової відповідальності держави в Україні не $\epsilon$ на сьогодні завершеним. Свідченням тому $\epsilon$ слабкість таких елементів зазначеного інституту, як процедурно-процесуального складника, брак визначеності у співвідношенні адміністративних і судових (процесуальних) елементів у процесі реалізації конституційно-правової відповідальності держави, незавершеність юридизації системи конституційно-правових санкцій у сфері відповідальності держави.

Ґрунтовне наукове осмислення структурних особливостей конституційно-правової відповідальності держави має слугувати практичним цілям упорядкованості й систематизації в конституційно-правовому регулюванні зазначеного інституту в системі інститутів конституційного права з метою оптимізації інституційної спроможності відповідного правового феномену - юридичної відповідальності держави.

\section{Література}

1. Липинский Д.А. Макроуровень института юридической ответственности. Право. Журнал Высшей школы экономики. 2019. № 1. С. 25-44.

2. Федоренко В.Л. Внутрішня побудова інституту конституційного права: проблеми теорії та практики. Юридичний вісник. 2013. URL: http://www.pravnuk. info/2013-12-27-15-15-31/768-vnutrishnya-pobudovainstitutu-konstitucijnogo-prava-problemi-teori\%D1\%97-tapraktiki.html.

3. Липинский Д.А. К вопросу о структуре института юридической ответственности. Вектор науки ТГУ. 2011. № 4(7). С. 57-63.

4. Кондрашев А.А. Теория конституционно-правовой ответственности в Российской Федерации : автореф. дисс. на соискание ученой степени доктора юрид. наук: спец. 12.00 .02 «Конституционное право; муниципальное право». Москва, 2011. 56 с.

5. Темникова М.П. Роль конституционно-правовой ответственности в укреплении конституционной законности и построении конституционного государства. СевероКавказский юридический вестник. 2017. № 3. С. 112-117.

6. Мамбетова К. Некоторые теоретические аспекты конституционно-правовой ответственности в Рос- 
сийской Федерации. Право и управление. XXI век. 2013. № 1(26). С. 124-132.

7. Институты конституционного права : монография / Л.В. Андриченко, А.Е. Постников и др. Москва : Юриспруденция, 2013. 496 с.

8. Постников А.Е. Тенденции развития институтов конституционного права. Журнал российского права. 2011. № 10. С. 27-34.

9. Калинин С.А. Понятие и структура правовой системы. Право и демократия. 1999. Вып. 10. С. 17-25.

10. Погорілко В.Ф., Федоренко В.Л. Конституційне право України за заг. ред. В.Л. Федоренка. Київ : Всеукраїнська асоціація видавців «Правова єдність», 2010. 432 с.

11. Шабуневич С.Н. Юридическая ответственность государства за нарушение конституционных прав и свобод личности в Республике Беларусь : автореф. дисс. на соискание ученой степени канд. юрид. наук: спец. 12.00.02 «Конституционное право; конституционный процесс; муниципальное право». Минск, 2019. 30 с.

12. Гецко В.В. Конституційно-правова відповідальність народних депутатів України та депутатів місцевих рад: проблеми теорії та практики : дис. канд. юрид. наук: 12.00.02. Ужгород, 2015. 195 с.

13. Виноградов В.А. Ответственность в механизме охраны конституционного строя. Москва, 2005. 420 с.

14. Демкова М.С., Коба С.С., Лавриненко І.О., Український Д.Я. Відшкодування в позасудовому порядку шкоди, завданої державою або органами влади. Київ : Конус-Ю, 2007. 260 c.

15. Яремчук С. Інститут відповідальності держави перед особою як форма реалізації гарантій прав і свобод людини та громадянина. Вісник Національного університету «Львівська політехніка». Серія: Юридичні науки. 2017. № 861. С. 567-573.

16. Конституційне право України: прагматичний курс : навч. посіб.; за заг. ред. М.В. Афанасьєвої, А.А. Єзерова; тех. ред. Ю.Д. Батан. Одеса : Юридична література, 2017. 256 c.

17. Рабінович П.М., Хавронюк М.І. Права людини і громадянина : навч. посіб. Київ : Атіка, 2004. 464 с.

18. Витрук Н.В. Общая теория правового положения личности. Москва : НОРМА, 2008. 448 С.

19. Ткаченко Ю.В. Форми (види) конституційно-правової відповідальності. Форум права. 2013. № 2. С. 549-555. URL: http://dspace.nlu.edu.ua/bitstream/123456789/5208/ 1/Tkachenko.pdf.

20. Ирошников Д.В., Гайдук С.Л. Конституционно-правовые санкции в теории позитивной ответственности. Юридическая наука. 2016. № 3. С. 10-14.

21. Колосова Н.М. Конституционная ответственность в Российской Федерации: ответственность органов государственной власти и иных субъектов права за нарушение конституционного законодательства Российской Федерации. Москва, 2000. 190 с.

Бакумов О. С., кандидат юридичних наук, доцент, доцент кафедри конституційного і міжнародного права факультету № 4 Харківського національного університету внутрішніх справ 